Deforestation, cattle capitalism and neodevelopmentalism in the Chico Mendes Extractive Reserve, Brazil

\title{
Kröger, Markus
}

2020-04-15

Kröger , M 2020 , ' Deforestation, cattle capitalism and neodevelopmentalism in the Chico Mendes Extractive Reserve, Brazil ', Journal of Peasant Studies , vol. 47 , no. 3 , pp. 464-482 . https://doi.org/10.1080/03066150.2019.1604510

http://hdl.handle.net/10138/323967

https://doi.org/10.1080/03066150.2019.1604510

unspecified

acceptedVersion

Downloaded from Helda, University of Helsinki institutional repository.

This is an electronic reprint of the original article.

This reprint may differ from the original in pagination and typographic detail.

Please cite the original version. 
Deforestation, Cattle Capitalism and Neodevelopmentalism in the Chico Mendes Extractive Reserve, Brazil

Markus Kröger, Journal of Peasant Studies, in Press, author's pre-print version (8 Feb 2019)

\section{Abstract}

The recent upsurge of deforestation inside conservation areas requires empirical investigation of the causes and consequences of this alarming process. Local relations between the agents of cattle capitalism, neodevelopmentalism and contemporary deforestation, from politicians and ranchers to the traditional extractive populations of multiple-use conservation areas, are assessed. Whether, when, and how state, market, and cultural institutions support the hegemony of cattle capitalism - and subvert the logic of traditional lived environments - are analyzed. Theoretically, the article shows how moral economic transformations, from rubber tapping to cowboy lifestyles, alongside nodevelopmentalist policies, enable regionally dominant political economies to expand through deforestation.

Keywords: Deforestation; cattle capitalism; Amazon; Brazil; moral economy; multiple-use conservation areas

\section{Introduction}

Deforestation - the long-term replacement of forest landscapes with pastures, mines, or tree plantations - and the degradation and fragmentation of forestlands are increasing around the world (Taubert et al. 2018). Tropical tree cover loss has spiked since 2016, with 2017 being the second-worst year recorded; Brazil tops the global list by far (with 4.5 million 
hectares lost in 2017), and most of this loss has taken place in the Amazon (World Resources Institute 2018). Given the worsening policy setting (Rochedo et al. 2018), the days of radically decreased deforestation rates are over, although many thought this problem had been solved (e.g., Thaler 2017). ${ }^{1}$

The election of Jair Bolsonaro as the president of Brazil in 2018 has created an expectation of skyrocketing deforestation, especially in areas that had previously been left in relative peace, such as conservation and indigenous areas (Pontes 2019). Forest degradation within multiple-use conservation areas had already begun to increase before Bolsonaro's election (Pedlowski et al. 2005; Imazon 2017). Several policies by recent governments directly or inadvertently paved the way for greater deforestation inside conservation areas, as I shall show here through a discussion of what happened in Acre's famous Chico Mendes Extractive Reserve (CMER) before the Workers' Party (PT)-led front lost almost all its power in Acre to the supporters of Bolsonaro in the 2018 elections.

In the 1970s, the Acre rubber tappers started to demand de jure and state recognition for their established de facto territorial practices that were communally organized and consisted of family and larger commons: they sought not only land but specifically forest so that they could expand their avocation as rubber tappers (Porto-Gonçalves 2006, 168). This model was enshrined in subsequent de jure rights (Kröger and Lalander 2017). Arguably, the clear-cut slowdown period and low figures of 2012 were largely the result of a long sociopolitical process - 'socioenvironmentalism' (socioambientalismo; see. e.g., Porto-

${ }^{1}$ In 2012, a record low (but still high) area of only $4,571 \mathrm{~km}^{2}$ was clear-cut in the Brazilian Amazon, but by 2016, the figure had jumped to $7,989 \mathrm{~km}^{2}$ (Spera et al. 2016). 
Gonçalves 2006; Gudynas 2016) - that valorized biodiversity and sustainable forest-based livelihoods (see, e.g., Hochstetler and Keck 2007; Hecht 2011). Forest people's mobilizations during the Lula government led to the establishment of many new extractive reserves (RESEXs) and other units that conserved large forest areas as a cornerstone policy of creating barrier zones at the resource frontier (Hecht 2011; Fraser 2018). However, currently, rising deforestation inside conservation areas is eroding the power of the very core of this policy the territorialized political process based on strong forest dwellers' mobilization (see Fraser et al. 2017) - which brought much deforestation to a halt. The process of deforestation inside the CMER, described here as it happened before Bolsonaro's election, is likely to expand.

Global extractivism is currently expanding in many countries through the political means of authoritarian agrarian populism (Scoones et al. 2018), in which alliances of politicians with neoliberal, conservative-theocratic and coercive policies are a way for large capitalists to break the power and territories of organized rural populations seeking to protect their lived environments. The 'populist' part of this authoritarianism is well presented by the dynamics of the CMER and Acre. According to the five presidents of CMER's five producer associations and a trade union president operating inside the CMER (personal communications, 25 January 2019), $70 \%$ of the people in the CMER voted for Bolsonaro, who promised to 'give a gun and a course on how to use it to everyone and let the whole of the Chico Mendes Reserve be deforested to build ranches.' The discussion here helps us to understand how we got here, i.e., to see such authoritarianism (in relation to life; people and forests) as a partial consequence of the prior extractivist neodevelopmentalism. 
Global extractivism comes in many forms; before the current authoritarian era, it took the form of neodevelopmentalism (see Hall and Branford 2012), of which a key element was the policy of the 'progressive' Latin American governments to promote logging, plantations, mining and/or ranching expansion on supposedly more equal social terms or to offer part of the overall extractivist rents as social welfare benefits to the excluded sectors, such as rural populations (Baletti 2014). However, this neodevelopmentalism has been deeply contradictory and conflictive as a policy from the very beginning (North and Grinspun 2016), as through massive support of corporations and infrastructure (Hall and Branford 2012), as well as other policies aiding mass-scale extraction, neodevelopmentalism has benefited the entrance of capital at the cost of the environment and the poor who depend on its actually (and not just discursively) sustainable use (Vergara-Camus and Kay 2017).

Neodevelopmentalism has exacerbated the existing power relations by granting most of the new power to the approximately 5,000 elite families of Brazil, offering greater possibilities for them to accumulate capital and political economic power through expanding the financialized commodity sectors (Kröger 2012). The thrust that has gained even more force in Brazil since approximately 2010, which has been characterized as 'postenvironmentalism,' features strong support for agribusiness, the creation of land markets, and the application of monetary value to environmental services (de Toledo et al. 2017).

In this article, I will analyze how these and other possible dynamics have influenced and play out in the rapid expansion of ranching and the concomitant rise in deforestation within the CMER in Acre. The CMER is iconic given its namesake - if it fails, its loss will be much more symbolic than the failure of other RESEXs. The CMER is situated next to the borders of Peru 
and Bolivia and a major interoceanic highway and presents a barrier to a major and established ranching/logging frontier (Maciel et al. 2018). ${ }^{2}$

I offer general notes on the different kinds of ranchers within the CMER and through which types of relations they expand pastures. I argue that this pasture expansion is enabled by a moral economic change, which is visible on a subjective level as a change from extractivist attitudes and habitus towards a cowboy mentality and social relations that is promoted by the regionally dominant political economy. This change in landscape has major future consequences in that forest-based moral and political economies can no longer be sustained or developed in pasturelands, which means that in a few generations, extractivist subjectivities may also vanish, as they are territorialized habituses. ${ }^{3}$

${ }^{2}$ These contextual features make the pressure of deforestation much greater there than, for example, in the Tapajós-Arapiuns RESEX in Pará, which has no road access or nearby land access to pastureland expansion (although there are many other factors of deforestation).

${ }^{3}$ Another parallel change that has begun to occur is the institutional-legal redefinition of RESEXs to accommodate cattle. The territorialized habituses change to ranchers through specific processes of 'intersubjective transformation' and connections (see Fraser 2018 for a framework on how to analyze such changes in detail). In a prior study, Hoelle $(2015,144-$ 146) argued that migrants in National Institute of Colonization and Agrarian Reform (INCRA) settlements have taught the neighboring rubber tappers cattle raising and how to obtain 'profits from land'. Hoelle believed that deforestation in the CMER would be kept under control, as it takes place mostly at the 'fringes'; most of the CMER inhabitants are protected from becoming deforesting actors due to the 'land-tenure system in structuring practice' in 
By the concept of cattle capitalism, and based on recent interviews and insights from forest dwellers in the Amazon, ${ }^{4}$ I show how ranching expansion inside conservation areas is

an institutionalized way in RESEXs. However, as I show, the land-tenure system has in practice already changed to an informal land market, and the moral economic transformation seems to enable the expansion of ranching deep inside the CMER.

${ }^{4}$ My analysis is based on participant observation among forest dwellers in different parts of the Brazilian Amazon since 2005, including several weeks of multisited political ethnography (see Schatz 2009) in Acre in May 2017 and in Pará in February 2018, expert interviews with powerholders in Brasília in November 2018, and other data that offer a comparative perspective on the longer-term research apparatus. Multiple data sources are used: policy documents (including internal ICMBio and government documents to which I was given access); semistructured interviews (30 in Acre in 2017); observation of dialogues; and statistics. These discourses were transcribed. I gathered knowledge about the changing lived environments by participant observation, which included moving about the pastures and forests targeted by capital with the involved social actors, asking them on site to discuss past or foreseen forest cover changes, and spending time among actual policymakers particularly the conservation authorities, forest dwellers and activists but also politicians and cattle ranchers. The collected data were used to assess the four essential questions suggested by Bernstein (2010): Who owns what? Who does what? Who gets what? What do they do with it? Expert interviews and longer-term interactions with people were used in process-tracing the answers to these questions to open up the causalities of deforestation. Providing answers to these questions makes the power play involved in agrarian political 
indicative of a more general moral and political economic transformation to capitalism wherein the consideration of long-term sustainability is replaced by the search of fast profits at any cost. I understand cattle capitalism as being formed through a series of relations and events (to be discussed in the next section) that link local ranches to consumers of meat and other ranching products. As this chain is a long and complex one, it must be studied in parts: here, I focus on starting from the site of local production expansion to see how in practice the meat production system can penetrate even protected Amazon rainforest areas.

Scholars attempting to identify the most efficient antideforestation policies globally have found that such policies vary depending on the commodity frontier in question (Nolte et al. 2017). It is therefore important to study the type of capitalist system or commodity frontier in operation in the transformation of different landscapes (see Moore 2015; Gudynas 2016; McKay 2017). When such distinctions are not made, people confuse proximate and ultimate causes, allocating the agency and responsibility for deforestation to the wrong actors (as many journalists, researchers, bureaucrats, and politicians still do), ${ }^{5}$ such as the laborers engaged in the physical work of destruction at the frontiers of deforestation. Although there is a large and rich literature on the structural and agency causes behind deforestation in the Brazilian Amazon (e.g., Campbell 2015; Hecht 2007; Fearnside 2017; Foweraker 1981; Hall and Branford 2012), the rise in deforestation inside conservation areas such as the CMER

economy more visible, and assessing these factors allows the exploration of relations between political economy/development policies and deforestation.

\footnotetext{
${ }^{5}$ See, e.g., https://www.newscientist.com/article/dn27993-brazils-resettlement-of-farmershas-driven-amazon-deforestation/ (accessed 7 January 2018).
} 
that has already occurred since the 2000s has not received enough critical attention. ${ }^{6}$ The analysis here seeks to open up some of the complexities in the ultimate and proximate causes of deforestation.

My concept of cattle capitalism addresses just one slice of the large and complex political economic system linked to beef and pastures: I assess how deforestation takes place through a push by nearby large and medium-sized ranchers with whom (ex-)rubber tappers make deals to illegally 'lease' their forestlands for pasture conversion or start to ranch themselves inside the multiple-use conservation areas where they control land. I study how the establishment of 'cattle capitalism' inside areas that did not previously have ranches is related to deforestation and supported by neodevelopmentalism. I study here just one 'variety of cattle capitalism' that operates inside Brazil. Other, partly interrelated causes of deforestation inside the CMER, such as neodevelopmentalism, logging, and the demise of extractive economies and their support, are also discussed. Through my concept of cattle capitalism, I want to show that it is not just any form of capitalism but a particular 'environmental variety of capitalism,' which means that this commodity frontier has particular impacts on lived environments. I analyze how peasants, including rubber tappers living inside conservation areas, can be subsumed under cattle capitalism. I will use the case of Acre and an iconic multiple-use conservation area there to start to decipher how a vortex

\footnotetext{
${ }^{6}$ Some general studies on the CMER have commented on the deforestation caused by ranching expansion (e.g. Vadjunec et al. 2009; Maciel et al. 2018; Mascarenhas et al. 2018), but these authors have not engaged in the critical analysis of this important phenomenon.
} 
of state, market, and cultural institutions support the hegemony and advance of cattle capitalism at the local level.

The dominant economic groups, such as the meat corporations, gained relatively the most capital even under the Workers' Party (PT) governments (Kröger 2012). Meanwhile, the subsidies and other support for establishing and opening export markets for forest dwellers' non-wood-based products waned and vanished almost completely, causing, for example, the collapse of rubber-tapping economies (see Jaramillo-Giraldo et al. 2017). These interrelated processes are perhaps the most direct economic explanations for why many (ex-)rubber tappers - 'agro-extractive' (see Fraser et al. 2018, 1383) and other families living inside the CMER - have allowed cattle into the reserves, creating patron-client partnerships with largescale ranchers, becoming in practice their workers and subsuming their land under the imperatives of cattle capitalism. I explore this primary claim and finding.

I will first introduce what I mean by 'cattle capitalism' and explain how this concept helps in studying a key driving process of deforestation. Second, I will unite E.P. Thompson's (1963; 1971) theory of moral economy with political economic analysis to open up when, how, and why ranching expansion occurs or is resisted inside the CMER, i.e., provide tools for analyzing the enabling processes of deforestation. In the third section, I will search for varied explanations for the deforestation by exploring the ranching and agro-extractive economies in the CMER and the roles of roadbuilding, tenure and labor systems and their changes. In the final section, I will analyze cattle capitalism through the interactive dynamics of state, business, and resistance actions (see Kröger 2013), such as the role of neodevelopmentalist policies and objections to them, as this analysis can shed light on the issues of responsibility and key agency in driving deforestation. The conclusions section provides broader 
theoretical lessons, relates them to Brazil's new authoritarian populism, and summarizes the findings.

\section{The Relations of Cattle Capitalism with Deforestation}

In Brazil, recent policy measures favor an accelerated expansion of one of the most degrading of land uses, the burning of primary rainforests to plant grasslands for ranching (Fraser 2014). Irregularity is rampant, and environmental state institutions are seriously understaffed, with the Brazilian Institute for the Environment and Renewable Natural Resources (IBAMA) and the Chico Mendes Institute for Biodiversity Conservation (ICMBio) having only about ten officers each to monitor illegal deforestation (and other issues) in Acre. According to a director of IBAMA (author's interview, Brasileía 22 May 2017, translated from Portuguese), currently, 'the biggest challenge [in Acre] is the rise in deforestation' due to pervasive ranching. ICMBio officers are fighting against an extremely serious process of increased deforestation within many conservation areas. The CMER is the most threatened protection area in Brazil (Imazon 2017). ${ }^{7}$ Established in 1990 and spanning 931,537 ha, it is a

\footnotetext{
${ }^{7}$ The situation in Acre has deteriorated in the direction forecast by Salisbury and Schmink (2007), who assessed the struggle between cattle and rubber in an Acre Sustainable Development Project (PDS), an INCRA settlement undergoing a major process of deforestation via cattle expansion. As INCRA and environmental authorities have not really tackled this deforestation, many of my informants perceived that the key state organs had been colonized by logging/cattle interests.
} 
multiple-use conservation area, a model that has been argued to have multiple benefits visà-vis strict conservation areas (Gomes 2009, 30) - or, at the least, to be the most salient and expedient form of conservation, both politically and practically (Fearnside 2017). ${ }^{8}$ Amazonian peasants have typically had only a few cows for milk and sustenance (Allegretti 1990). I observed, however, that herds of dozens, even hundreds, of cattle have become a common sight inside the CMER. There are thus different political and moral economies related to cattle; broadly speaking, Brazilian 'cattle capitalism' could be argued to take two main forms, 'primitive' and 'modern'.

The 'primitive' form of cattle capitalism is directly dependent on large territorial expansion: it is an established system based on land theft and speculation as forms of value creation as well as sales of timber and attempts to enclose the illegally seized lands by deforesting and fencing them and placing pasture and cattle on the areas (author's interview, Ane Alencar, IPAM, Brasília, 23 November 2018). This wasteful process represents an estimated $80 \%$ of Brazilian ranching and is causally related to a rampant form of deforestation that is not interested in soil quality or improving the sustainability and yields of ranching via intensive pastureland management (which would be an example of a 'modern' variety of cattle capitalism) (see Fearnside 2017).

The beef production complex in Brazil is supported by the continued provision of cheap rural credit and expansionist government policies that favor the largest meat-processing

\footnotetext{
${ }^{8}$ There is already ample evidence that forest cover is generally much better retained in indigenous lands and conservation units (e.g. Nepstad et al. 2006); these have been mostly outside the reach of capitalisms.
} 
corporations (JBS and Marfrig, the two largest, had received the equivalent of approximately 3 billion dollars in subsidies as loans from the National Bank for Economic and Social Development (BNDES) by 2010), and ranching in the Amazon is a consequence of these land use and development policies (Merry and Soares-Filho 2017). ${ }^{9}$ Although Brazil is the world's leading exporter of bovine meat, the national consumption is more than five times higher than the export volume - and the Amazon, and particularly Acre, has the highest per capita beef consumption (Hoelle 2017). ${ }^{10}$ According to my informants (author's interviews, January 2019), the CMER herd has a 'guaranteed market,' as there are large buyers in Acre; the largest freezer company is Betão, which exports the meat to southeastern Brazil and 'all around.' Even in Xapuri, there are 'approximately 8 buyers' who have ' 11 large cattle trucks, who sell to 1-2 corporations.' Interestingly, these eight buyers and truck owners come from 'within the reserve': they are middlemen linking the national meat capitalists and markets with the deforested CMER pastures: 'those who operate this buying, and deliver the meat to the freezers, are the sons of the rubber tappers from here within.' 'The sons of the natives already feel that they dominate a part of this economy,' and this 'incentivizes the cattle raising,' as this small group of people is increasingly powerful in creating the market

\footnotetext{
${ }^{9}$ There is no space here to discuss at length what happens in the upper echelons of the 'value web' of cattle capitalism, such as the Brazilian congress and the world's largest meat producers (which are Brazilian and closely linked with the congress).

${ }^{10}$ Per capita beef consumption in Acre has been estimated at 42.25 kilograms per year. Of the 9.67 million tons of beef produced in Brazil in 2013, only 1.6 million were exported; the rest was consumed in Brazil.
} 
channels within and for the expanding cattle capitalist system. This activity creates a worrisome 'type of illusion' that one could be better off with cattle, and many people follow the illusion 'without planning,' resulting in only very few (some of the middlemen) experiencing economic improvement.

Deforestation is contingent upon the specific time (e.g., the year or season), place (e.g., near rivers or in the western, southern or eastern Amazon), and phase (e.g., new frontier or postfrontier) of the process (Fearnside 2017), and this contingency is amply emphasized by the political ecology of the Amazon (e.g., Schmink et al. 2017). Many studies have suggested different causes - Hoelle (2017), for example, emphasized consumer responsibility and the magic of fetishized commoditization as the mechanism hiding the link between consumption and environmental damage. But detailed research examining cattle capitalism as a political economic system of local and broader-scale power has yet to be undertaken (see, however, Adams 2015; Hoelle 2015; Taravella and Sartre 2012); this article is a step in that direction. To this end, I will next study regional moral economic changes to better understand when, how and why the drive for cattle capitalism advances, i.e., what local changes enable the drive to result in deforestation.

\section{The Role of Regional Moral Economies in Deforestation}

A comparison of the regional moral economies of peasants has been fruitful in explaining why rural development schemes have succeeded or failed in different parts of Brazil (Wolford 2010), leading me to study how changes in the moral economy of the ex-rubber tapping, extractive populations of the Amazon might also function in certain circumstances as enabling factors for deforestation within the conservation areas that these populations 
change through their daily practices and decisions about (forest) land use. The concept of 'moral economy' is derived from the work of E.P. Thompson $(1963 ; 1971)$ and refers to the importance of historically established and underlying regional customs, context, and culture in explaining why certain political economic changes and policies fail, succeed, encounter opposition, or cause demobilization (see, e.g., Wolford 2010, 7-8). Thompson $(1963,63)$ used moral economy to refer to normative attitudes about social relations and behavior in immediate economic activities. Moral economy is a useful concept of interpretation and explanation to explain such peasant-related transformations for several reasons.

First, Thompson (1971) found the concept to be useful to explain the resistance by peasant societies whose customary landholding regimes were being challenged by capitalist advances that were destroying these regimes and thus bringing about the end of prior lifestyles. Additionally, in the CMER, the resistance to illegal ranching/logging is based on arguments related to an older moral economy that is enshrined in the discourses and struggle of Chico Mendes. These arguments teach that the destruction of forests, especially by unfair methods such as illegal ranching that jeopardize the neighbors and lead to the ills of capitalism that Chico Mendes fought against, is immoral because it subverts the goal that the leader of the rubber tappers set for them and other forest populations in his famous words: 'At first I thought I was fighting to save the rubber trees; then I thought I was fighting to save the Amazon rainforest. Now I realize I am fighting for humanity.' In this way, 'moral economy' can be used as the basis of a systemic analysis of what happens at the social level within a process of conflictive deforestation inside a multiple-use conservation area.

Second, Thompson (1963) argued that a violation of the traditional norms that guide the productive and social systems is a violation of the existing moral economy. I will use moral 
economic discourses referring to such violations (or defending them as actual improvements rather than violations), as found in my observations of speeches inside the CMER, as an indicator and starting point to analyze how and why deforestation expands inside RESEXs. This aspect of moral economy guides the analysis to consider how the moral economy has been formed historically and how it is currently changing and affecting the environment. As, e.g., Hoelle $(2015 ; 2017)$ has documented, Acre has been undergoing massive transformation in relation to its (de)valuation of forests and increased valuation of beef consumption and the ranching way of life. Ane Alencar, the director of the Amazon Environmental Research Institute (IPAM), argued (author's interview, 23 November 2018) that there is an important social component explaining deforestation inside the CMER: 'to be extractivist is considered a poor thing in the Amazon, while the rancher casts an image that he has money,' and as the rubber economy has been devalorized, 'the new generation do not see themselves as rubber tappers.' In addition to this intergenerational territorial capture by cattle capitalism, I will show how these moral economic processes of change have been partly and paradoxically supported by certain features of the existing rubber tapper moral economy (although these processes are also still partly challenged by the environmentalist and forest-defending activist aspects of this moral economy). ${ }^{11}$ The study

${ }^{11}$ At the political and moral economic levels that I am assessing here, the current rubber tapper moral economy has several paradoxes that revolve around cognitive dissonance about the rising valuation of beef (requiring deforestation) and the lingering importance of forests. Rubber tappers agreed the most of all the different social groups interviewed by 
of these moral economic struggles offers insights into how ranching is allowed or not allowed to expand.

\section{Cattle Capitalism as a Regionally Dominant Form of Extractivism and Deforestation}

After taking the ferry across the Acre River in Xapuri on the way to the CMER, one sees the text 'The Slaughterhouse of the Rubber Tapper' written in outsize letters in Portuguese above a large painting of a cow on the wall of a building. Cristina Silva (author's interview May 2017), the manager of CMER at ICMBio, with a long history of working for the rubber tappers' organizations around Brazil, told me that the CMER is Brazil's most problematic RESEX 'in terms of the number of people, cattle, and pasture':

If we are not careful, Chico Mendes will turn into a cattle pasture.... The greed for pasture and timber, and above all for cattle, is driving up the number of irregular occupations. Many people are selling and buying land (colocação), although they are not allowed to do this... a total mess. It has become a free market.

The process of deforestation inside the CMER has accelerated, especially since the 2012 Forest Code (Mascarenhas et al. 2018), ${ }^{12}$ but its roots lie in the 1980 s. According to an old

Hoelle $(2017,751)$ with the statement that 'a lunch with no meat leaves a person weak' (90 percent agreed, while $70 \%$ of cowboys and $15 \%$ of NGO respondents agreed).

12 The 2012 New Forest Code (Law № 12.651) increased deforestation in Brazil (Kröger 2017). Already before then, the 2006 Law of Management of Public Forests (№ 11.284) had increased logging schemes (Kröger 2018), which degrade forests and thus increase fires, 
activist (author's interview May 2017, Brasileía), 'this business of mass deforestation started in 1980 and has gained traction since then'; although the bulk of the direct pressure from large-scale ranchers was stopped in the late 1980s by the rubber tappers, 'the small farmers continued' deforesting.

\section{Economic Explanations: Cattle and Rubber Economies}

Since the time of Chico Mendes, there has been a substantial change in the economic profile of the forest-dwelling people. According to the Brazilian Institute of Geography and Statistics (IBGE), the number of cattle remained at approximately 60,000 and 70,000 between 1990 and 2000 in the important municipality of Xapuri but then tripled between 2000 and 2005 (from 76,200 to 190,986) (cf. Gomes 2009, 73). The 2000-2005 period clearly marked an epochal shift, after which cattle started to spread deeper into the CMER. The president of

opening up terrain for the subsequent expansion of pastures and other forms of deforestation (Fearnside 2017). On the positive side, the Lula government's Action Plan for the Prevention and Control of Deforestation in the Legal Amazon (PPCDAm) was effective in curbing Amazon deforestation rates, but the third phase of this plan, called Fostering Sustainable Production (2012-2015), did not result in lower deforestation (see http://redd.mma.gov.br/en/legal-and-public-policy-framework/ppcdam). This third phase focused on production, a policy concomitant with constantly rising forest degradation and deforestation rates inside multiple-use conservation units since 2011 (see Table 1 herein for the government figures: http://www.mma.gov.br/informma/item/616- 
one of the five CMER dwellers and producers' associations, Associação dos Moradores e Produtores da RESEX - CM em Xapuri (Amoprex), Tião de Moises, explained how this process has been unfolding:

Today, we have many people in the reserve who do not have the extractivist profile and only come here to possess land for sport, to hunt, to fish, to cut wood... thinking that a cut-down forest makes more sense than a standing one... ICMBio does not take care of this, and no one observes the actions of the state government: the situation is truly bad.

The absence of state policies is most clearly visible in the reduction of subsidies for rubber by not providing a high enough fixed price for it. Several ex-rubber tappers told me that the prices of rubber and meat explained the transformation towards deforestation:

Today, as the purchase of rubber has ceased, they have started to destroy the forest to plant grass to raise cattle, to produce [parir] calves to sell them and buy food. When the rubber had a price, nobody had cattle, but when the price of rubber fell... (author's interview with an extractivist, May 2017, Xapuri)

Cattle ranching started to be seen as a way to get money faster than was possible by traditional forest-based livelihoods; beef cattle were already seen as a useful although despised form of insurance among former rubber tappers (Salisbury and Schmink 2007) thus, there was already a hoofprint to be expanded inside the CMER. Acrean rural trade union leaders were also beginning to have a positive view of cattle as a source of improved income for those living inside forests (see the excerpt in Gomes 2009, 103). However, many 
told me that the gains associated with cattle should not be overemphasized. ${ }^{13}$ Declining productivity on Amazonian cattle frontiers typically forces ranchers to move deeper into forests within $10-15$ years; smallholders are a particular case in point, as they do not have the access to capital that the larger-scale ranchers have to improve their production methods (Schmink et al. 2017, 15).

There is an ongoing debate about the meaning of sustainability and development and how to achieve them in multiple-use conservation areas. The creation of forest-based income opportunities was already a key concern for those observing RESEXs from the onset of their establishment in the early 1990s: Brown et al. (1992) noted that 'adverse changes in income patterns for rubber tappers could lead to abandonment of extractive reserves or increased deforestation within them.' This result is what we are witnessing now in several parts of the CMER as the impacts have flowed outward from the dominant economic system to reach even those who were once stalwart activists on behalf of rubber tappers.

The battle between cattle and rubber is also a moral economic struggle in which discursive arguments about the available possibilities for income and livelihoods are key: as two informants said, 'cattle has liquidity' and 'cattle fattens if left alone for a month, while latex spoils.' For the pro-forest dwellers, the key would be for the state to create an overarching and differentiated development policy for the Amazon and its forest populations, increasing

\footnotetext{
${ }^{13}$ In the current inefficient system (Fearnside 2017, 23), which relies on 'using the Amazon as a frontier' for expanding beef cattle production at a rate of one head per hectare (author's interview, Cassio Alves, INIAMA, Belém 25 January 2018), cattle profits are short term and seriously infringe on future survival possibilities.
} 
the budget for subsidies to buy their products, expanding value-added production in the Amazon, and providing technical and administrative support in greater quantity (author's interview, Cassio Alves, INIAMA, Belém 25 January 2018).

There are no publicly available data on the production of forest commodities in the CMER. However, based on my interviews with experts with access to the official statistics, between 2001 and 2015, the production (in tons) of açai grew from 108 to 1,912 and of Brazil nuts from approximately 1,400 to 6,100 . Thus, two important sources of income have been developed. Nonetheless, some informants who are close to the state government observed that these figures are not enough to justify the current use of the territory, arguing that much more should be produced. They further cited figures showing that the production of rubber decreased from 863 to 25 tons, indicating that rubber tapping is vanishing.

Consequently, for a long time, the key income source for most 'rubber tapper' families has not been the rubber collected by the menfolk but rather agriculture and the collection of nuts and other nonrubber forest products (Hecht 2007, 342).

According to an expert informant, there was a dramatic increase in the number of cattle in Acre between 2001 and 2015: from 1.6 million to approximately 2.9 million. ${ }^{14}$ In the CMER there are already herds numbering over 700. An ex-manager of the CMER told me (author's interview, 12 January 2019) that there are three forms of ranching expansion inside the RESEX:

${ }^{14}$ The publicly available IBGE figure for 2014 is 2.8 million. 
1. People buy a small herd of their own, up to 30 head, 'for sustainability of himself, not to become rich, just for security.'

2. 'De meia': people have the land and rent to a farmer to place cattle there, gaining a few head for themselves. The herds can be up to 100 head.

3. The ex-rubber tapper parcels his colocação illegally with the help of the rancher and sells this public land in lots for ranching: 'The number of these cases is incalculable.' The person 'does not become rich; he/she ends up selling the land and the cattle but does not manage to leave behind its poor living conditions. He remains chained to the [large outsider] rancher, who keeps wanting more and more from the person and giving very little back in return.'

Most deforestation takes place through the second and third routes: there are 'many people doing these' to 'do the production of de meia' or to 'divide the place,'15 in this third option, 'the people lose the control.' Between 2011 and 2016, 92\% of deforestation inside the CMER took place due to the expansion of the existing ranches; their average size, worryingly, more than doubled during this period - leading to a situation in which seringais that have been

15 'De meia' refers to 'half,' as sometimes in these irregular 'contracts,' the peasant gets half of the cattle that have been raised after the 3-4 year period by him. According to Tião de Moises (25 January 2019), the (ex-)rubber tappers assume the risks and costs in this case: they use so much of their own labour time and money to set up the ranch (pasture seed, pesticides, salt, etc) that 'they do not make money with this but live deceived,' while the one 'who gained was the large rancher [who provided the initial herd], as the herd grew and fattened, and he took half of it.' 
deforested by over $20 \%$ have become the norm inside the CMER (Mascarenhas et al. 2018). Furthermore, forest degradation is much greater than this clear-cutting figure.

The process is not uniform: by 2016 , over 1,000 ha of 28 of the 46 seringais in the CMER had been deforested and over 2,000 ha of ten seringais; only ten had less than 500 ha deforested (see Mascarenhas et al. 2018, 246). This discrepancy requires an explanation. I will next analyze the government and resistance politics and policies that help to explain where and how ranching expanded. This analysis illustrates that while the change in economic opportunities discussed above did play a role, politics and the active forging of contentious agency (see Kröger 2013, discussed below), or the absence of resistance to ranching, were important in defining where pasturelands expanded and where they did not. The interplay between government strategies, capitalist expansions and resistance - in their impact on the moral economy - needs to be analyzed to explain the politics of deforestation.

\section{The Dynamics of Cattle Capitalism, Neodevelopmentalism, and Resistance Agency}

Government policies, even by the PT-led coalitions, have greatly expanded ranching inside the CMER. This expansion illustrates how even well-intended social welfare expansion has caused under-the-radar deforestation and environmental degradation when a key government policy has promoted the type of neodevelopmentalism that the Frente Popular do Acre (FPA) coalition governments adopted (see Fantini and Crisóstomo 2009). The FPA ruled Acre between 1999 and 2018. The parties composing it fluctuated, but some have argued that the PT, the Communist Party of Brazil (PC do B), the Brazilian Socialist Party 
(PSB), and the Party of National Mobilization (PMN) composed the decision-making core. ${ }^{16}$ According to Sant'Ana Junior (2006), there is a long-standing divide within this coalition between those in favor of sustainability or development ('sustentabilistas' and 'desenvolvimentistas'); for the latter, as early as 2000 , sustainable development no longer signified environmental development that would privilege ecology and preservation; they saw the Amazon's forests as a source of great wealth, as money signals that could be turned into capital. This division within the coalition has been seen as resulting in a schizophrenic government that retained the initial environmentalist slogans mostly as tools of political marketing (Pinheiro 2010) and used the environmental discourse to silence the multiple knowledges of the forest populations and indoctrinate those populations to accept the government policies, which are no longer as much in favor of forest protection as of expanding ranching (Passaro 2012).

The CMER still has a well-organized social movement of rubber tappers, but this resistance is a shrinking minority. Organizing and politicizing a mass social movement whose core ideology is to retain a lived environment with rich standing forests is a key strategy in forging this resistance agency. ${ }^{17}$ This strategy influences the moral economy. Communities where

\section{${ }^{16}$ See http://www.vermelho.org.br/noticia/20231-1 (accessed 17 January 2019)}

${ }^{17}$ Organizing and politicizing are two separate tactics for creating social movements (see Kröger 2013). By resistance agency, I refer to strategies of resistance that forge activists, that is, increase contentious agency; this is not thus just any type of isolated resistance act but signifies a broader process of creating new and more lasting collective, territorialized habituses, through a particular set of strategies. 
this strategy continues to be fostered by activists have seen much less or no deforestation, in contrast to those where the ideology of ranching and/or logging, swift revenue, and consumption-based life trajectories has gained hold, as I observed across the different regions of the CMER and in Pará RESEXs. At one meeting that I attended, the old activists criticized a proposed increase in forestry through selective logging as mere fantasy that would lead to pastureland in practice. They tried to persuade the people to remain true to their rubber tapper roots, as illustrated by these words of a senior political leader in May $2017:$

Do you think that for the number of years that I've lived here, if I deforested, this forest would exist? It wouldn't; there would be only pasture. This is why my colleague here argued that cattle are not sustainable, and I agree with him. It is inhumane to have [ranching] in the forest because it is the biggest enemy of the forest and for our region. I hate and fear deforestation.

While this type of support of forest-conserving moral economies existed especially among the families and communities of older activists, the expansion of cattle capitalism inside the reserve especially attracted young people who had finished their schooling, had gone to work for commercial ranchers and were consequently learning the modes of production and lifestyles of ranchers:

You can't imagine how many people are using agro-toxics and turning their backs on latex extraction, helping their parents, and the exploration of good things. Why? Because they study, finish their high school but have nothing to do; so they end up as spreaders of poison for ranchers. Once they return from there, their minds have been shaped by ranching, and they take a large stretch of forest from their parents 
and put it to grass and cattle... Before, the rancher stayed outside of the reserve, but today, he is inside here. (Author's interview, Tião de Moises) ${ }^{18}$

A medium-scale rancher made the implicit point that the large ranchers are not worried about the cattle causing deforestation:

They don't care... they want to make it possible for everybody to have cattle; they want to help. If you have a farm with an extra 50 hectares of pasture, they will give you the cattle and offer you $50-70 \%$ of the sales price for you to stay calm. They are in need of land at times, as their pastures grow too small [for their oversized herds]. Therefore, they search for someone to whom they can cede their cattle.

Deforestation continues, as the state and municipal governments are not trying to amend the situation: 'I do not see this as an issue to which the mayors, or even the city councilors, would pay attention. The cooperative is seeing this happening and is worried, but the government is not very attentive about this.' In addition, Tião de Moises claimed that among the key policies driving deforestation in the CMER were 'the delivery of roads and electricity

${ }^{18}$ There has been a generational change: many young people no longer know what uses trees can have or what trees there are and are unaware of the forest around them. However, they do not have the same social, cultural or economic capital as their city peers to seek urban jobs. According to my informants, many CMER teenagers have ended up in marginal positions and in prisons as they have moved away from the reserve. 
for all, bolsa familia (family grants), and rural credit,' which are directed primarily and almost solely towards ranching expansion. ${ }^{19}$

New systems of valuation and moral and political economies are also built by the circulation of specific discourses, in particular by those in power, and these challenge the old moral economy. The ongoing and strongly moral discourses attacking and defending the advance of logging and ranching inside the CMER are a sign of the underlying moral economy being challenged. The modern moral economy of the neodevelopmentalists and those in favor of neoliberal individualistic enrichment has discourses of its own that challenge the claims that deforestation for ranching would be bad - also on moral and ethical grounds - and new customs of what is considered just usage of territories and the right type of economic activity. I observed a PT municipal councilor from Brasileía arguing at a public meeting inside the reserve for the need to 'develop,' which would also be possible by allowing ranches: 'The forest cannot interfere in human lives; it must complement them.'

The municipal councilor went on to promote the idea that trees should be used to make furniture and other valuable wood-based products, explaining that he is in favor not of complete conservation but of 'sustainable management.' 'Poverty' was framed as the key problem and getting rich as the goal: 'We have the greatest wealth in the world, but we are poor: why? How can it be that I am a gold miner and do not have a gold ring on my finger? There is no justification for this, right?' Education and sustainability were thus embedded in

${ }^{19}$ The seringais close to the towns of Xapuri, Brasiléia and Epitaciolândia have become the most deforested, and the existence of access roads explained about $80 \%$ of deforestation in a 2013 study (Mascarenhas et al. 2018). 
a worldview in which trees seen primarily as timber were an integral element of development, and no problems were envisaged in the promotion of cattle inside the reserves; rather, the councilor saw the expansion of cattle-based industries alongside logging as providing a joint solution to problems of development. These messages, however, echoed Bolsonaro's speeches much better than the official Workers' Party policy of 'florestania' in Acre: in January 2019 (author's interviews), the majority of people in the CMER had come to accept the view that 'other countries and states deforested out there, and now we should pay for this?,' which explains the new moral and political economy in which 'the natives themselves inside the reserve see that destruction is the only path.' The president of Amoprex, Tião de Moises, noted that the youths consider what they are living through and seeing - the process of deforestation - a normal state of affairs: one makes a living by getting rid of the forest and expanding pastures.

Have you wondered how many children and students are assisting in the destruction of the forest..., the division of colocações and the illegal sale of the parcels, timber extraction, the spreading of poisons, the devastation of the forest...? They are going to grow up seeing this.... It is being destroyed; nobody values it. (Author's interview 23 May 2017)

In a follow-up interview on 25 January 2019, Tião de Moises explained that although 'clandestine loggers' and outsiders are expanding pastures, the people who 'cut all the trees in their areas and sell them clandestinely to put pastures there' are the 'children of the natives from within the reserve.' These younger members of the community learned to live within this model. They do not want to collect latex or nuts anymore, saying that this gives little money. They want to get rid of the trees and plant 
pastures. This became a habit for them as if they were ranchers; he is the guy with the bull, the guy with the boots, the guy with the brimmed hat, with the lasso, understood?

The prevalence of these types of stories is a clear indicator that not all supposed welfare policies, such as schools and roads extended in a general manner, result in an improvement in the quality of life. Many of these neodevelopmentalist measures reduce the possibility of continuing the extractivist way of living and, moreover, transform the children of rubber tappers into agents of deforestation. These findings suggest that the intertwining of extractive capitalism and neodevelopmentalism, including the expansion of social policies and access to forest dwellers, is causally connected to deforestation and forest degradation. The expansion of schooling that is not tailored to the needs and realities of the Amazon agro-extractive populations living inside conservation areas, the spread of modern valuations of urban life, and Acre's strong cowboy culture that surrounds the CMER are partial explanations of how the surrounding political and moral economy has changed a multiple-use conservation area into the pursuit of more 'development' and less conservation.

\section{Conclusions}

This study has assessed the dynamics of deforestation and conservation in the Amazon through the lens of the state of Acre in Brazil, particularly the CMER by analyzing forest cover changes in this pivotal multiple-use conservation area. This article focused on the CMER in order to track the local dynamics by which cattle capitalism is expanding, driven by a process that extends from top-level politicians and large ranchers to (former) rubber 
tappers living within a conservation area. The analysis sheds light on the causes of deforestation by illustrating how neodevelopmentalist welfare policies that are considered benign can also drive deforestation, especially 1) when taking place inside conservation areas and 2) in regions where deforesting sectors dominate the political economy. Furthermore, 3) this political economic analysis was united with a study of moral economic struggles to analyze how and why deforestation takes place. The findings are also relevant for the natural sciences, which have found that the Amazon is rapidly changing due to the interplay of climate change and increased infrastructural and large-scale projects causing deforestation (Fearnside 2017). The synergistic interactions stemming from forest clearing, fragmentation, logging, and fire may eventually force the Amazon into a gradual process of savannization (Nobre et al. 1991); indeed, this is the current prognosis, given the Bolsonaro government's policies supporting deforestation. Thus, the political and moral economic causes studied here are increasingly important in order to understand and govern the changing climate and political ecology.

E.P. Thompson's (1963) concept of moral economy was used to explain the underlying transformations and the deeper and historically built socioeconomic structures that partially enabled the push of cattle capitalism in this particular moral economic context. Acre rubber tappers have a history of being exploited through the aviamento system, which did not allow them to form the extensive agricultural settlements or autonomy and mutuality-based relations that were developed in the relatively less dominated regions of the Amazon, such as the Madeira River, studied by Fraser et al. (2018). The idea, even after driving out bosses and stopping ranchers, was for the people to extract rubber and other non-wood-based products and to process these products for the market through their own cooperatives. However, this concept was a very large attempted leap from the prior indentured debt 
relations - Chico Mendes and his fellow activists were attempting to overcome the burden of centuries of accumulated moral economic thinking and feeling about what kinds of economic relations one should make a living by, and with whom. With the advance of cattle capitalism, the CMER is witnessing a similar 'return of the moral economy' of colonial-type relations, as the rubber tappers no longer produce for their own cooperatives but instead accept offers of cheap labor and forestland access from outside capitalists to become once again the access point for those seeking wealth based on using forests (including destroying them through logging/ranching) and to take a small slice of the returns as 'extractivists' linking the extractor and the extracted commodity.

The weakness of mass resistance in the present-day CMER, in the form of the united blockades of logging and pasture expansion that the rubber tappers organized in the 1970s and 1980s, is indicative of the serious weakening and porousness of the underlying moral economy of forest populations who seek to 'live from, in, and for forests' (as the CMER promotional posters still propose). In a Marxist sense, this weakening is indicative of a process whereby the moral economy of the rubber tappers has lost power vis-à-vis 'raw money power' as money has increasingly become the basis for community 'dissolving the traditional community' (see Harvey 2010, 294). However, the ranching expansion is also indicative of the strengthening of another moral economy whose values, customs, and legitimizing beliefs regarding the consensus of the wider community (see Thompson 1971, 50) are derived from an individualistic, consumerist and immediatist cowboy culture. This is 'greed for and by cattle; they think that money comes fast through ranching,' as an ex-CMER manager told me (author's interview, 12 January 2019). 'Cattle is the ambition'; getting more cattle and expanding the herd become the goals; and 'capitalism forces him to think in this 
way; he thinks that the cattle are his security and will take him out of misery, while in reality, he is going deeper into misery.'

Theoretically, while the business part of de facto selling the forest for logging and 'leasing' the land for ranching are signs of what Thompson (1963) would consider a vanishing of the 'peasant moral economy,' I suggest that the neodevelopmentalist and even the cowboy culture are rather signals of a 'modern moral economy,' mixing the idealism of consumerism and welfare increase at the cost of the forests. The changes in the moral and political economy studied here help to explain why the leftist parties lost almost everything to Bolsonaro and his allies in Acre. In terms of Thompson's $(1971,98)$ view of peasant moral economy as a legitimator of peasant protests, the fierce speeches of Bolsonaro and his allies against land occupations and other forms of socioenvironmental protest should be seen as attempts to make preemptive strikes against the well-established 'popular ethic' in Brazil that sanctions 'direct action by the crowd'; at the same time, it should be noted that Bolsonaro's apparatus focuses on delivering new moral economic points of reference for the people based on a variety of Brazilian conservative Christianity. These points of reference should be seen as attempts to strike at the root mechanisms of how 'contentious agency' in general is built (see Kröger 2013).

Instead of arguing that the expansion of modern individual property rights (as e.g., de Soto 1989 argues and the Temer and Bolsonaro government agrarian reform policies are carrying out) or access roads within the RESEXs are the solution (as the neodevelopmentalist 'progressive' politicians also did; see Gudynas 2016), the findings presented here suggest that actions of this sort do not lead to the desired outcomes, as the dominant economic sector, in this case cattle capitalism, abuses them. Gladson Cameli, Acre's new governor as 
of 2019 , has promised to turn the state into a vast soybean plantation, favoring corporations; e.g., Blairo Maggi has said that he wants to buy 20,000 hectares of land in Acre for soybean cultivation (Pontes 2019). Cameli has promised tenure security without the need to worry about environmental rules, and the state's new environmental minister is a rancher. The $80 \%$ increase in deforestation in Acre in 2018 is likely to be supplanted by an even higher figure in 2019 (ibid.); thus, Acre is likely to emulate the prior deforestation pattern in Rondônia, where conservation areas have been seriously fragmented (see Pedlowski et al. 2005). Indeed, Cameli wants Acre to follow the model of Rondônia.

The findings presented in this article suggest that several interlinked, underlying but also agentive processes seem to drive deforestation and cause an increasing number of rubber tappers to contribute to it: 1) the spread of de facto individual property rights and 2) universal modernizing neodevelopmentalism (extending roads, schooling, electricity) that is not suited to the realities of Amazonian multiple-use conservation areas. These two processes are used by the surrounding ranching, logging and land speculation frontier through which 3) cattle capitalists and other dominant economic groups seek to expand into conservation areas and increasingly succeed when 4) subsidies for non-wood-based forest products are cut, 5) the number and resources of environmental officers are reduced to a bare minimum, and 6) the forging of contentious agency is made more difficult and fails in numerous places due to 7) generational changes dividing lands and making collective decision making harder, particularly as 8) youngsters have been steeped in the region's impeding cowboy culture, and 9) the turning of prior forest-valuing progressive politician allies into supporters of logging and ranching inside conservation areas legitimizes and seeks to hide this transformation and counter the resistance. 
Building roads and extending power lines deep into the RESEXs (instead of, for example, creating electricity without extensive grids) and offering access to ranching credit have led, directly and indirectly, to greater deforestation, both by those living inside the reserves and by outsiders. Furthermore, developmental discourses that frame the existing lives, livelihoods, and lived environments of people without these basic provisions as backward or miserable, promulgated both by right-wing and left-wing politicians, are not helping; rather, they ease the 'modernization' of forest areas by transforming them into cattle country. Further theorizing of 'cattle capitalism' as a specific environmental variety of capitalism, with regional variations and several subparts - which, for example, drive deforestation - should be undertaken in future research.

\section{References}

Adams, R. 2015. 'An emerging alliance of ranchers and farmers in the Brazilian Amazon'. Tipití, 13: 63-79.

Allegretti, M. 1990. ‘Extractive Reserves: An Alternative for Reconciling Development and Environmental Conservation in Amazonia.' In Alternatives to Deforestation: Steps Towards Sustainable Use of the Amazon Rain Forest, edited by A. Anderson, 52-64. New York: Columbia University Press.

Baletti, B. 2014. 'Saving the Amazon? Sustainable soy and the new extractivism.' Environment and Planning A 46(1): 5-25.

Bernstein, H. 2010. Class dynamics of agrarian change. Halifax: Kumarian. 
Brown, F., Nepstad, D. C., Pires, I. D. O., Luz, L. M., and Alechandre, A. S. 1992. 'Carbon storage and land-use in extractive reserves, Acre, Brazil.' Environmental Conservation, 19(4): 307-315.

Campbell, J. 2015. Conjuring property: Speculation and environmental futures in the Brazilian Amazon. Seattle: University of Washington Press.

de Soto, H. 1989. The other path. New York: Harper \& Row.

de Toledo, P.M., Dalla-Nora, E., Vieira, I.C.G., Aguiar, A.P.D. and Araújo, R. 2017.

'Development paradigms contributing to the transformation of the Brazilian Amazon: do people matter?' Current Opinion in Environmental Sustainability, 26: 77-83.

Fantini, A., and Crisóstomo, C. 2009. 'Conflitos de interesses em torno da exploração madeireira na Reserva Extrativista Chico Mendes, Acre, Brasil.' Boletim do Museu Paraense Emílio Goeldi. Ciências Humanas 1(1): 231-246.

Fearnside, P. 2017. 'Deforestation of the Brazilian Amazon.' In Oxford Research Encyclopedia of Environmental Science edited by H. Shugart. New York: Oxford University Press.

Foweraker, J. 1981. The Struggle for Land: A Political Economy of the Pioneer Frontier in Brazil from 1930 to the Present Day. Cambridge: Cambridge University Press.

Fraser, B. 2014. 'Carving up the Amazon.' Nature, 509(7501), 418.

Fraser, J.A., Cardoso, T., Steward, A. and Parry, L., 2017. 'Amazonian peasant livelihood differentiation as mutuality-market dialectics.' The Journal of Peasant Studies, 45: 13821409.

Fraser, J.A. 2018. 'Amazonian struggles for recognition.' Transactions of the Institute of British Geographers, 43(4): 718-732. 
Gomes, C. 2009. 'Twenty years after Chico Mendes: Extractive Reserves' expansion, cattle adoption and evolving self-definition among rubber tappers in the Brazilian Amazon.' PhD diss., University of Florida.

Gudynas, E. 2016. 'Beyond varieties of development: disputes and alternatives.' Third World Quarterly, 37: 721-732.

Hall, A., and Branford, S. 2012. 'Development, dams and Dilma: the saga of Belo Monte'. Critical Sociology, 38(6): 851-862.

Harvey, D. 2010. A Companion to Marx's Capital. Verso.

Hecht, S. 2007. 'Factories, forests, fields and family: Gender and neoliberalism in extractive reserves.' Journal of agrarian change, 7(3): 316-347.

Hecht, S. 2011. 'From Eco-Catastrophe to Zero Deforestation? Interdisciplinarities, Politics, Environmentalisms and Reduced Clearing in Amazonia.' Environmental Conservation, 39: 419.

Hochstetler, K., and Keck, M. 2007. Greening Brazil: Environmental Activism in State and Society. London: Duke University Press.

Hoelle, J. 2015. Rainforest cowboys: the rise of ranching and cattle culture in Western Amazonia. University of Texas Press.

Hoelle, J. 2017. 'Jungle beef: consumption, production and destruction, and the development process in the Brazilian Amazon.' Journal of Political Ecology, 24: 743-762. Imazon. 2017. 'Ameaça e pressão de desmatamento em áreas protegidas: SAD de agosto an outubro de 2017.' Accessed 21 February 2017. 
http://imazon.org.br/PDFimazon/Portugues/transparencia_florestal/Ameaca\%20e\%20Press ao_SAD_agosto\%20e\%20outubro\%202017.pdf

Jaramillo-Giraldo, C., Soares-Filho, B., Ribeiro, S., and Gonçalves, R. 2017. 'Is It Possible to Make Rubber Extraction Ecologically and Economically Viable in the Amazon?' Ecological Economics, 134: 186-197.

Kröger, M. 2012. 'Neomercantilist capitalism and post2008 cleavages in economic decisionmaking power in Brazil.' Third World Quarterly, 33: 887-901.

Kröger, M. 2013. Contentious Agency and Natural Resource Politics. London: Routledge.

Kröger, M. 2017. 'Intersectoral Determinants of Forest Policy: The Power of Deforesting Actors in Post2012 Brazil.' Forest Policy and Economics, 77: 24-32.

Kröger, M. 2018. 'The new "sustainable communitarian" logging schemes and their critique inside multiple-use conservation areas in the Brazilian Amazon: preliminary notes.' Globalizations 15(5): 581-592.

Kröger, M., and Lalander, R. 2016. 'Ethno-territorial rights and the resource extraction boom in Latin America: do constitutions matter?' Third World Quarterly, 37: 682-702.

Maciel, R.C.G., et al. 2018. 'The "Chico Mendes" extractive reserve and land governance in the Amazon.' Journal of environmental management 223: 403-408.

Mascarenhas, F., Brown, F., and Silva, S. 2018. 'Desmatamento e incêndios florestais transformando a realidade da Reserva Extrativista Chico Mendes.' Desenvolv. Meio Ambiente 48: $236-262$.

McKay, B.M. 2017. 'Agrarian Extractivism in Bolivia.' World Development, 97: 199-211. 
Merry, F., and Soares-Filho, B. 2017. 'Will intensification of beef production deliver conservation outcomes in the Brazilian Amazon?' Elem Sci Anth. 5(24).

Moore, J.W. 2015. Capitalism in the Web of Life. Verso Books.

Nepstad, D., Schwartzman, S., Bamberger, B., Santilli, M., Ray, D., Schlesinger, P.,... and Rolla, A. 2006. 'Inhibition of Amazon deforestation and fire by parks and indigenous lands.' Conservation biology 20(1): 65-73.

Nobre, C., Sellers, P., and Shulka, J. 1991. 'Amazonian deforestation and regional climate change.' J. Clim. 4: 957-988.

Nolte, C., de Waroux, Y.L.P., Munger, J., Reis, T.N., and Lambin, E.F. 2017. 'Conditions influencing the adoption of effective anti-deforestation policies in South America's commodity frontiers.' Global Environmental Change, 43: 1-14.

North, L., and Grinspun, R. 2016. 'Neo-extractivism and the new Latin American developmentalism: the missing piece of rural transformation.' Third World Quarterly 37(8): $1483-1504$

Passaro, E. 2012. Um contexto histórico e sócio-ambiental dos povos da floresta do Acre. UNESP. https://repositorio.unesp.br/handle/11449/120416

Pedlowski, M.A., et al. 2005. 'Conservation units: A new deforestation frontier in the Amazonian state of Rondônia, Brazil.' Environmental Conservation, 32(2): 149-155. Pontes, F. 2019. O agro é pop, o Acre é agro. http://www.fabiopontes.net/2019/01/o-agroe-pop-o-acre-e-agro.html (accessed 22 January 2019).

Porto-Gonçalves, C.W. 2006. 'A Reinvenção dos Territórios.' In: Los desafíos de las emancipaciones en un contexto militarizado, pp.151-197. Buenos Aires: CLACSO. 
Rochedo, P., et al. 2018. 'The threat of political bargaining to climate mitigation in Brazil'. Nature Climate Change 8: 695-698.

Salisbury, D. S., and Schmink, M. 2007. 'Cows versus rubber: changing livelihoods among Amazonian extractivists.' Geoforum, 38(6): 1233-1249.

Sant'Ana Junior, H. 2006. Desenvolvimento e Conservação Ambiental: Políticas SócioAmbientais do Governo do Acre. III Encontro da ANPPAS.

Schatz, E., ed. 2009. Political Ethnography. Chicago: University of Chicago Press.

Schmink, M., Hoelle, J., Gomes, C., and Thaler, G. 2017. 'From contested to 'green' frontiers in the Amazon? A long-term analysis of São Félix do Xingu, Brazil.' The Journal of Peasant Studies. doi: 10.1080/03066150.2017.1381841.

Scoones, I., Edelman, M., Borras Jr, S.M., Hall, R., Wolford, W. and White, B. 2018. 'Emancipatory rural politics: confronting authoritarian populism.' The Journal of Peasant Studies, 45(1): 1-20.

Spera, S., Galford, G., Coe, M., Macedo, M., and Mustard, J. 2016. 'Land-use change affects water recycling in Brazil's last agricultural frontier.' Global change biology, 22: 3405-3413. Taravella, R., and Arnauld de Sartre, X. 2012. 'The symbolic and political appropriation of scales: A critical analysis of the Amazonian ranchers' narrative.' Geoforum, 43: 645-56.

Taubert, F., et al. 2018. 'Global patterns of tropical forest fragmentation'. Nature 554: 519522.

Thaler, G. 2017. 'The Land Sparing Complex.' Annals of the American Association of Geographers.

Thompson, E.P. 1963. The Making of the English Working Class. New York: Vintage Books. 
Thompson, E.P. 1971. 'The moral economy of the English crowd in the eighteenth century.' Past \& present, 50: 76-136.

Tollefson, J. 2018. 'Brazil's lawmakers renew push to weaken environmental rules.' Nature 557: 17.

Vadjunec, J., Gomes, C., and Ludewigs, T. 2009. 'Land-use/land-cover change among rubber tappers in the Chico Mendes Extractive Reserve, Acre, Brazil.' Journal of Land Use Science, 4: 249-274.

Vergara-Camus, L., and C. Kay. 2017. 'Agribusiness, peasants, left-wing governments, and the state in Latin America: An overview and theoretical reflections.' Journal of Agrarian Change 17(2): 239-57.

Wolford, W. 2010. This Land is Ours Now. London: Duke University Press.

World Resources Institute. 2018. '2017 Was the Second-Worst Year on Record for Tropical Tree Cover Loss', by Weisse, M. and E. Goldman. http://www.wri.org/blog/2018/06/2017was-second-worst-year-record-tropical-tree-cover-loss (accessed 14 August 2018) 